\begin{tabular}{|c|c|c|}
\hline \multirow{3}{*}{$\begin{array}{l}\text { EREM 74/4 } \\
\text { Journal of Environmental Research, } \\
\text { Engineering and Management } \\
\text { Vol. 74 / No. } 4 \text { / } 2018 \\
\text { pp. 53-59 } \\
\text { DOl 10.5755/j01.erem.74.4.21073 } \\
\text { @ Kaunas University of Technology }\end{array}$} & \multicolumn{2}{|c|}{$\begin{array}{c}\text { Changes in Soil Properties and Heavy Metals Concentration in Soil of } \\
\text { Military Shooting Range in Central Lithuania }\end{array}$} \\
\hline & Received 2018/06 & Accepted after revision 2018/10 \\
\hline & \multicolumn{2}{|c|}{ erossef http://dx.doi.org/10.5755/j01.erem.74.4.21073 } \\
\hline
\end{tabular}

\title{
Changes in Soil Properties and Heavy Metals Concentration in Soil of Military Shooting Range in Central Lithuania
}

\author{
Jūratė Česynaitè, Gintarè Sujetovienè
}

Vytautas Magnus University, Faculty of Nature Sciences, Vileikos g. 8, LT-44404 Kaunas, Lithuania

Corresponding author: gintare.sujetoviene@vdu.lt

G. Sujetovienè, Vytautas Magnus University, Faculty of Nature Sciences, Vileikos g. 8, LT-44404 Kaunas, Lithuania

The aim of the study was to investigate the changes in physical properties and contamination with heavy metals of military shooting range soil. Field soil was collected from outdoor shooting range soils in central Lithuania. The shooting range is located in Alytus city. Physico-chemical examination showed that the $\mathrm{pH}$ value of the shooting range soil was described as alkaline (7.91-8.30). A decrease in organic matter content was established in soil samples taken from the backstop berm of a shooting range; moreover, increased soil density was discovered in all soil samples. The soil was heavily contaminated with $\mathrm{Pb}, \mathrm{Ni}, \mathrm{Cd}$ and allowable quantities of $\mathrm{Cu}$. The backstop berm soil was heavily contaminated with lead (max. $653.33 \mathrm{mg} / \mathrm{kg}$ ); nonetheless, the limit concentration of lead was exceeded in the backstop berm soil. The concentration of cadmium found in the shooting range area (0-400 meters) varied from $17.42 \mathrm{mg} / \mathrm{kg}$ to $39.07 \mathrm{mg} / \mathrm{kg}$ and was higher than the concentration in the backstop berm $(p<0.05)$. The limit concentration of cadmium, which is $3 \mathrm{mg} / \mathrm{kg}$, was exceeded in all soil samples. Large amounts of nickel were found closer to the beginning of the firing line and decreased with an increasing distance from the firing line $(r=0.90, p<0.05)$. The limit concentration of nickel in the soil $(75 \mathrm{mg} /$ $\mathrm{kg}$ ) was exceeded at $100 \mathrm{~m}, 200 \mathrm{~m}$ and $300 \mathrm{~m}$ distances.

Keywords: contamination, heavy metals, soil pollution, shooting range. 


\section{Introduction}

Soil is a unique part of the ecosystem; however, pollution with heavy metals is the problem of increasing concern (Chibuike and Obiora, 2014). Naturally occurring heavy metals are often not available for biota, while metals from anthropogenic sources have high bioavailability (Khalilova and Mammadov, 2016). At high doses, all heavy metals become toxic and carcinogenic (Tchounwou et al., 2012). Heavy metals remain in ecosystems for long periods of time. Metals can be absorbed and accumulated in various parts of the plant. Soil organisms are directly exposed to soil and heavy metals. Therefore, heavy metals can lead to changes in soil microorganisms, for example, their size, composition, and activity. From the soil, metals can be washed into lakes, rivers, bays and consequently can easily enter the food chain and pose a serious threat (Khalilova and Mammadov, 2016; Sanderson et al., 2014). In general, mobility of heavy metals depends on the physicochemical properties of the soil (ph, organic matter, density, etc.) and properties of a heavy metal itself (Zeng et al., 2011).

The contamination of outdoor shooting range soil is a major environmental problem (Sanderson et al., 2012; Sanderson et al., 2014; Fayiga and Saha, 2016; Rodríguez-Seijo et al., 2017). After the battery industry, shooting activity is the second most important factor contributing to soil pollution with lead (Sorvari et al., 2006; Sanderson et al., 2012). Bullets consist of various amounts of heavy metal alloys ( $\mathrm{Pb}, \mathrm{St}, \mathrm{As}, \mathrm{Sn}$, $\mathrm{Se}, \mathrm{Mn}, \mathrm{Cd}, \mathrm{Cr}, \mathrm{Cu}$, and Ni) (Fayiga and Saha, 2016). High pollution by heavy metals is seen in the soil of military shooting ranges (Hardison et al., 2004; Ahmad et al., 2012; Perroy et al., 2014; Fayiga et al., 2016; Mariussen et al., 2016). The intensity of the shooting activity is a key factor determining the extent of pollution in the shooting range. Lead is the main component of bullets (>90\%), but various amounts of other heavy metals are also found in bullet mass (antimony, arsenic, bismuth, silver, copper, and nickel). It is clear that the risk assessment and management of these contaminated sites are required to ensure that contamination does not negatively affect the environment (Spuller et al., 2007; Conesa et al., 2010; Sanderson et al. 2014; Fayiga, Saha, 2016).
The aim of the study was to investigate the changes in physical properties and contamination with heavy metals of military shooting range soil in central Lithuania. It is crucial to investigate the contamination of active shooting ranges because of threat of harming effects that may occur to humans who are exposed to heavy metals, especially lead.

\section{Methods}

\section{Study sites and soil sampling}

Field soil was collected from outdoor shooting range soils in central Lithuania. The shooting range is located in Alytus city (N 54.373825, E 24.072171). The shooting range structure consists of three main elements: a fire line, a target line and a backstop berm. The shooting range is $400 \mathrm{~m}$ long and has target lines at different distances $(100 \mathrm{~m}, 200 \mathrm{~m}, 300 \mathrm{~m}$, and 400 $\mathrm{m})$. In the range, shooters practice and improve their skills by shooting from different distances with various caliber weapons. Samples were taken from seven plots (Fig. 1). Five samples were taken from the shooting range area in accordance with target lines, one sample was taken from the beginning of the firing line (at a $0 \mathrm{~m}$ distance), four samples were taken

\section{Fig. 1}

Structure of the shooting range

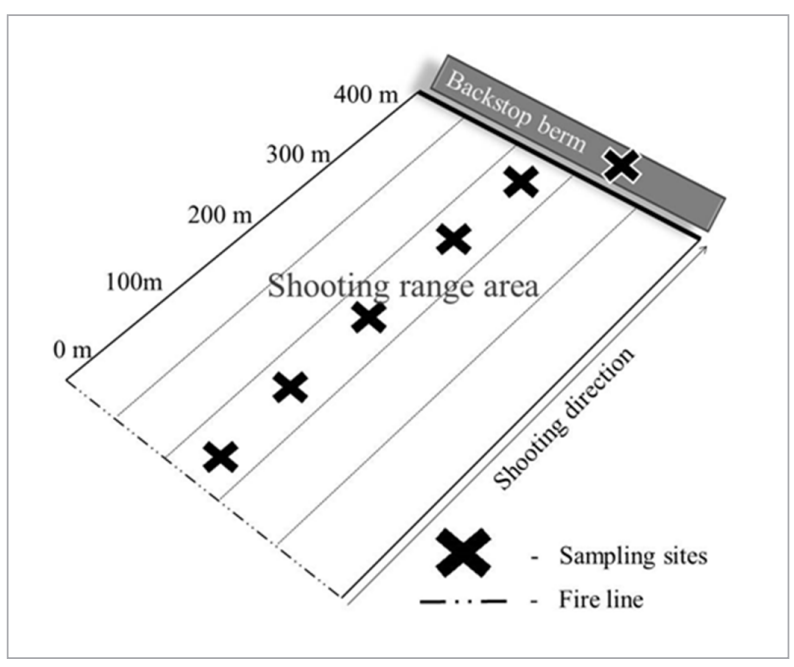


from target lines $(100 \mathrm{~m}, 200 \mathrm{~m}, 300 \mathrm{~m}, 400 \mathrm{~m}$ distances) and two samples were taken from the backstop berm (from the bottom of the berm and from $1 \mathrm{~m}$ height of the berm). At each distance, from a square plot $(0.5 \times 0.5 \mathrm{~m})$, five subsamples of the soil were collected from the corners and the centre of the plot using a cylindrical soil corer to a depth of $10 \mathrm{~cm}$. The samples from each plot were pooled and mixed thoroughly to get one representative composite sample at each studied plot. Grassland soil was collected in an unpolluted area of southern Lithuania $\left(54^{\circ} 25^{\prime} 42.8^{\prime \prime} \mathrm{N}\right.$ $24^{\circ} 14^{\prime} 07.5^{\prime \prime} E$, Pivašiūnai) and was used as reference.

\section{Physico-chemical analysis}

The soil samples were air dried, homogenised and sieved to less than a $2 \mathrm{~mm}$ grain size. The samples were stored in plastic bags prior to laboratory analysis. The $\mathrm{pH}$ was measured by potentiometric method, water ratio of 1:5 ( $\mathrm{pH}$ meter - inoLab 720, WTW). Organic matter content was determined by loss on the ignition method. Soil density was determined by pouring air-dry soil samples in a measured cylinder.

To analyse the contamination of the shooting range, lead as the main component of bullet mass was determined; copper, zinc, nickel, and cadmium as minor were components of bullet mass. To determine heavy metals $(\mathrm{Pb}, \mathrm{Zn}, \mathrm{Cu}, \mathrm{Ni}$, and $\mathrm{Cd})$ concentrations, approximately $0.5 \mathrm{~g}$ oven-dried soil samples were digested in $8 \mathrm{~mL}$ of $\mathrm{HCL}, 5 \mathrm{~mL}$ of $\mathrm{HNO} 3,5 \mathrm{~mL}$ of $\mathrm{HBr}$, and $3 \mathrm{~mL}$ of $\mathrm{HF}$ in a Teflon vessel using a microwave digestion system (Milestone Ethos One). Concentrations of heavy metals were determined by an atomic absorption spectrometer (Shimadzu AA-6800, Japan) with a graphite furnace atomiser (GFAAS). The elemental standard solutions were prepared by diluting a stock solution of $1,000 \mathrm{mg} \mathrm{L}^{-1}(\mathrm{~Pb}, \mathrm{Zn}, \mathrm{Cu}, \mathrm{Ni}$, and $\mathrm{Cd}$ ).

\section{Data analysis}

Analysis of variance (ANOVA) described the influence of distance from the firing line on the concentration of heavy metals. The t test was used for comparison of physical and chemical soil properties. Differences were considered significant when $p$ value was less than 0.05 . The Pearson correlation was used to determine the dependence of soil variables and the distance from the firing line. Programme STATISTICA 7 and MS Excel were used for the statistical analysis.

\section{Results and Discussion}

The $\mathrm{pH}$ values of the shooting range soil varied from 7.91 to 8.30 . The soil of shooting ranges was more alkaline compared with the control. The dispersion analysis revealed that the $\mathrm{pH}$ of shooting range soils was significantly higher than that of the control soil $(p<0.05$, Fig. 2A). A strong positive correlation between the distance of the shooting area (0-400 meters) and $\mathrm{pH}$ value was observed $(r=0.83, \mathrm{p}<0.05)$. These results are in accordance with those of Kelebemang et al. (2017) whoshowed that in different shooting ranges $\mathrm{pH}$ value varied from 6.81 to 8.69 . Similar results were observed by Sanderson et al. (2012): the $\mathrm{pH}$ of shooting range soil was from 5.3 to 9.3. It is known that the $\mathrm{pH}$ can affect solubility and mobility of heavy metals in soil (Kelebemang et al., 2017).

The higher organic matter content (mean 7.53\%) was at the shooting area of the range (from 0 to 400 meters) compared with the backstop berm (mean 4.51\%) (Fig. 2B). The analysis showed that the soil of the backstop berm was significantly lower in organic matter content compared with the control soil $(p<0.05)$. The mean density of the soil taken from the shooting area of the range was $1.29 \mathrm{~g} / \mathrm{cm}^{3}$ and the density of the backstop berm soil was $1.60 \mathrm{~g} / \mathrm{cm}^{3}$. The density of all soil samples was significantly higher than that of the control $(p<0.05$, Fig. $2 C)$. It was determined that the density of the soil taken from the backstop berm was significantly higher than in the samples of the shooting area of the range $(p<0.05)$. The density of soil particles varied from $1.84 \mathrm{~g} / \mathrm{cm}^{3}$ to $2.37 \mathrm{~g} / \mathrm{cm}^{3}$, and significant differences between the soil samples and the control were observed $(p<0.05)$ (Fig. 2D). The particle density of the soil taken from the backstop berm was significantly higher than in the samples of the shooting area $(p<0.05)$.

The highest concentration of lead in the shooting range was determined at the bottom of the backstop berm (Fig. 3A "Berm 0"), i.e., $653.33 \mathrm{mg} / \mathrm{kg}$, and in the samples taken from $1 \mathrm{~m}$ height of the backstop berm $(230.58 \mathrm{mg} / \mathrm{kg})$. At the distance of 200 to $400 \mathrm{~m}$, the lead concentration ranged from 20.48 to $38.94 \mathrm{mg} /$ $\mathrm{kg}$; and from the firing line to 100 meters, it ranged from 2.01 to $2.94 \mathrm{mg} / \mathrm{kg}$. The limit lead concentration (100 mg/kg, HN 60: 2004) in the soil was exceeded 
Fig. 2

Physical and chemical soil properties of the soil samples at the shooting area and the backstop berm (* indicates significant changes compared with the control soil)

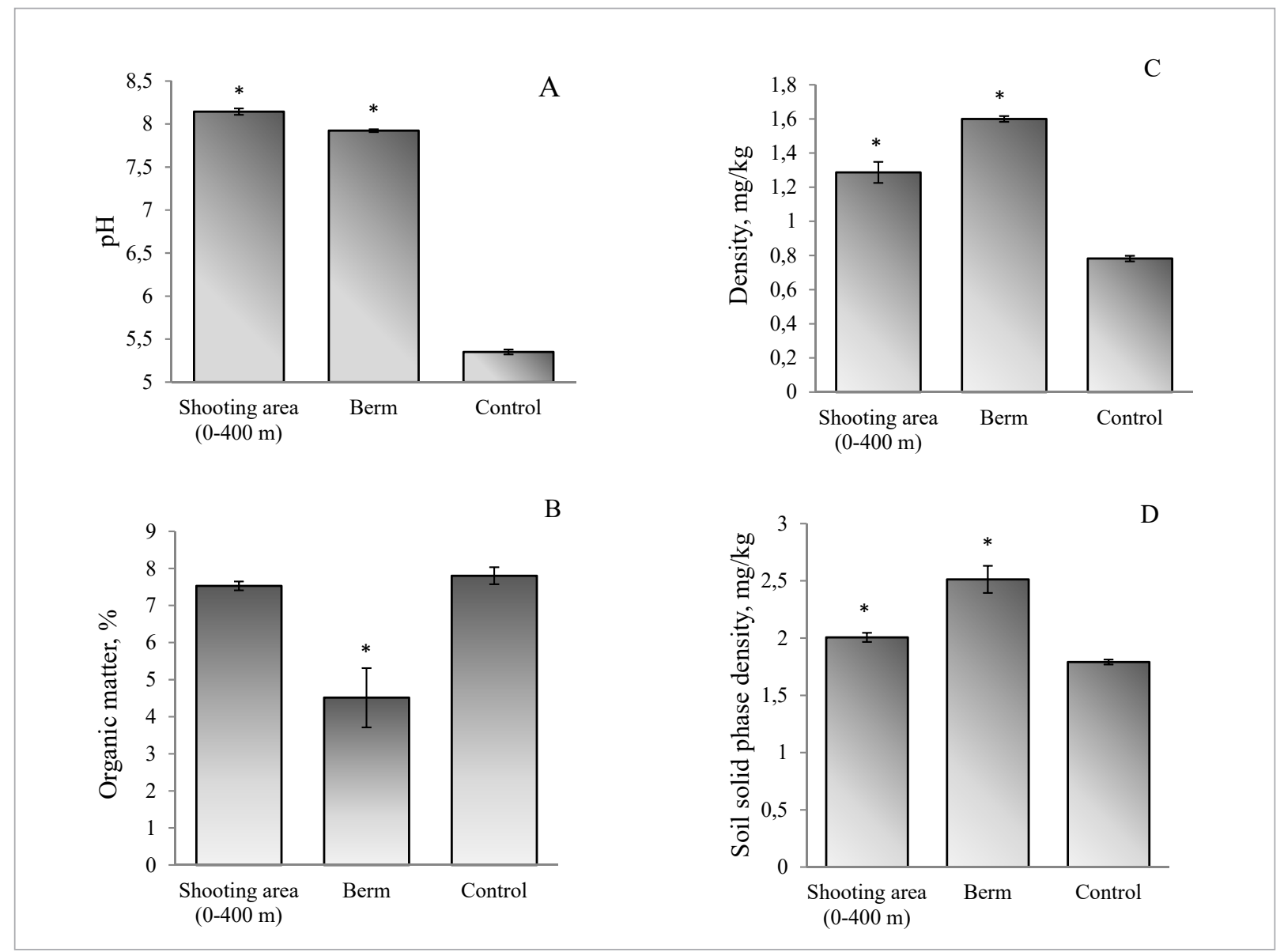

only in the backstop berm of the shooting range. It was determined that the concentration of lead in the backstop berm was significantly higher than in the shooting area $(0-400 \mathrm{~m})(\mathrm{p}<0.05)$.

The maximum concentration of copper was also found at the bottom of the backstop berm $(23.49 \mathrm{mg} /$ $\mathrm{kg}$ ). In the shooting area, the concentration of Cu varied from 0.75 to $9.59 \mathrm{mg} / \mathrm{kg}$ (Fig. 3B). The concentrations of copper in the backstop berm were significantly higher in comparison with the shooting area $(0-400$ m) $(p<0.05)$. The concentration of cadmium found in the shooting area of the range was higher than the concentration in the backstop berm $(p<0.05)$. At a distance of $0-400 \mathrm{~m}$, cadmium concentration varied from $17.42 \mathrm{mg} / \mathrm{kg}$ to $39.07 \mathrm{mg} / \mathrm{kg}$; however, in the backstop berm, the concentrations of cadmium were $6.16 \mathrm{mg} / \mathrm{kg}$ (berm 0) and $5.73 \mathrm{mg} / \mathrm{kg}$ (berm 1) (Fig. 3C). The limit concentration of cadmium (3 $\mathrm{mg} / \mathrm{kg}$ ) was exceeded in all soil samples.

Large amounts of nickel were found closer to the beginning of the firing line and decreased with an increasing distance from the firing line $(r=0.90$, $p<0.05$ ). In general, the concentration of nickel ranged from $3.12 \mathrm{mg} / \mathrm{kg}$ to $152.15 \mathrm{mg} / \mathrm{kg}$ (Fig. 3D). The limit concentration of nickel in the soil $(75 \mathrm{mg} / \mathrm{kg}$ ) was exceeded at $100 \mathrm{~m}, 200 \mathrm{~m}$ and $300 \mathrm{~m}$ distances from the firing line.

Physicochemical analysis revealed that the shooting range soil was affected by shooting activity. It is important to study soil properties because of different 
solubility of heavy metals at various conditions. For example, under the neutral soil $\mathrm{pH}, \mathrm{Pb}^{2+}$ is bound to clays, organic matter and iron (Fe) hydroxides (Tandy et al., 2017). In addition, cadmium seems to be less stable in soils compared with lead (Ahmadipour et al., 2015). Our study showed that organic matter content was lower in the area where bullets dropped (backstop berm), which is in accordance with the results observed by Murray et al. (1997). It is clear that organic matter content is one of the most important properties that determines quality, productivity and ecological functioning of soil (Kučerík et al., 2018). Therefore, our results clearly show that soil is adversely affected by shooting activity. Physico-chemical properties not only affect bullet weathering and availability of heavy metals, but also can increase chemical stabilisation and phytoremediation of these contaminants and can improve contamination management approaches (Seshadri et al., 2017).

A high concentration of lead was found in the backstop berm of the range. The shooting area contains back ground levels of lead. Similar results have been found by Kelebemang et al. (2017) and Sanderson et al. (2012). The study shows that the majority of lead is concentrated in the backstop berm soil as it collects used bullets. Interestingly, high concentrations of cadmium and nickel were found in the shooting range area. Although, the limit concentrations of $\mathrm{Pb}, \mathrm{Cd}$ and $\mathrm{Ni}$ were exceeded at several samples, in comparison with other research this shooting range

Fig. 3

Heavy metal concentrations of the samples taken from different sites of the shooting range $(\mathrm{A}-\mathrm{Pb}, \mathrm{B}-\mathrm{Cu}, \mathrm{C}-\mathrm{Cd}$, and $\mathrm{D}-\mathrm{Ni})$
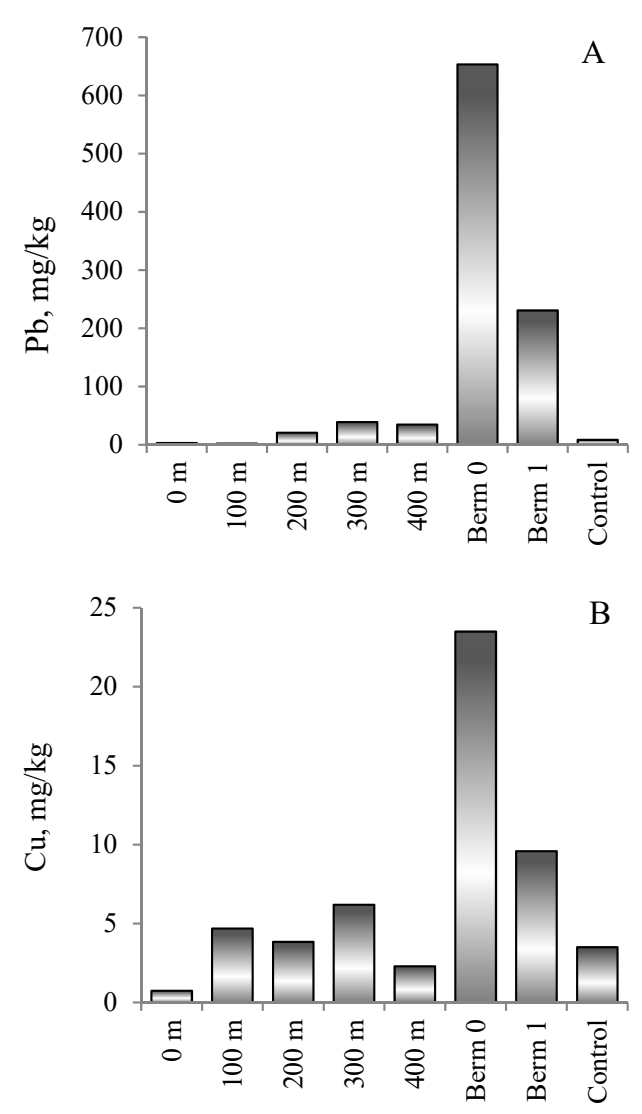
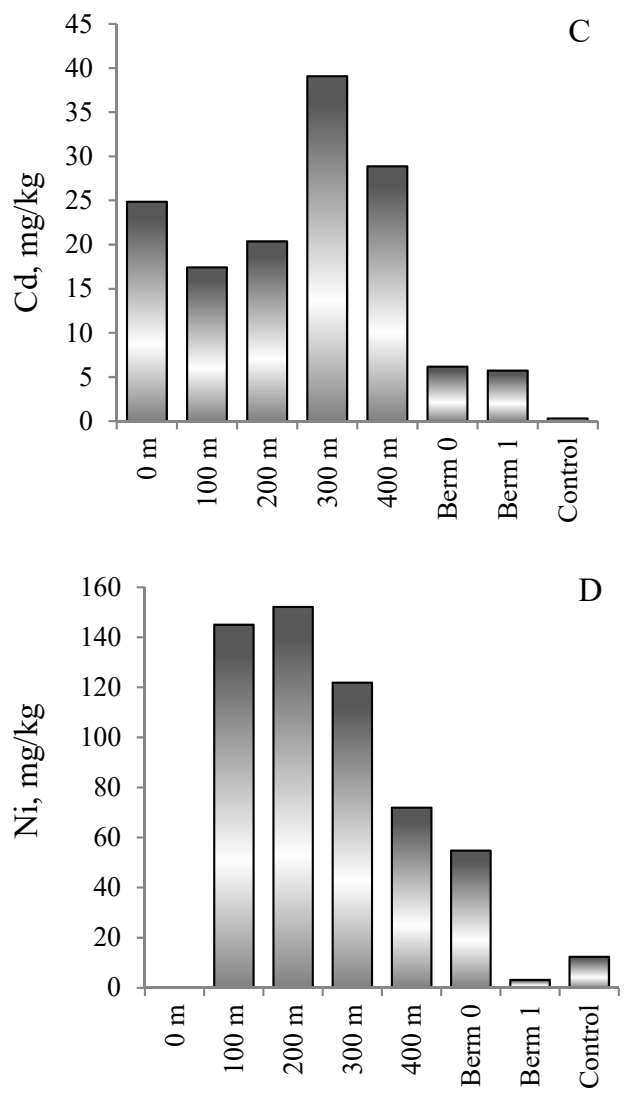
was not highly contaminated. Islam and Park (2017) found $3436 \mathrm{mg} / \mathrm{kg}$ lead; the maximum concentration of lead that Kelebemang et al. (2017) found in the soil of the shooting range was over $10,000 \mathrm{mg} / \mathrm{kg}$. Even abandoned shooting range soil is contaminated with lead from 160 to $720 \mathrm{mg} / \mathrm{kg}$ (Rodriguez-Seijo et al. 2016). Nevertheless, the contamination of the shooting range is serious and further investigations should be considered. However, differences of properties and contamination of heavy metals in soil of various shooting ranges suggest that overall contamination of shooting ranges is based on site-specific conditions. Therefore, a unique approach to contamination management should be applied.

\section{References}

Ahmad M., Moon D.H., Lim K. J., Shope C.L., Lee S.S., Usman A.R.A., Kim K., Park J., Hur S., Yang J.E. and Ok S. (2012) An assessment of the utilization of waste resources for the immobilization of $\mathrm{Pb}$ and $\mathrm{Cu}$ in the soil from a Korean military shooting range. Environmental Earth Science 67: 1023-1031. https://doi. org/10.1007/s12665-012-1550-1

Ahmadipour F., Bahramifar N. and Ghasempouri S.M. (2015) Fractionation and mobility of cadmium and lead in soils of Amol area in Iran, using the modified BCR sequential extraction method. Chemical Speciation \& Bioavailability 26(1): 31-36. https://doi.org/10.3184/095422914X13884321932037

Chibuike G.U. and Obiora S.C. (2014) Heavy Metal Polluted Soils: Effect on Plants and Bioremediation Methods. Applied and Environmental Soil Science 2014: 1-12. https://doi. org/10.1155/2014/752708

Conesa H.M., Wieser M., Gasser M., Hockmann K., Evandelou M.W.H., Studer B. and Schulin R. (2010) Effects of three amendments on extractability and fractionation of $\mathrm{Pb}, \mathrm{Cu}, \mathrm{Ni}$ and $\mathrm{Sb}$ in two shooting range soils. Journal of Hazardous Materials 181(13): 845-850. https://doi.org/10.1016/j.jhazmat.2010.05.090

Fayiga A. and O. Saha U.K. (2016) Soil pollution at outdoor shooting ranges: Health effects, bioavailability and best management practices. Environmental Pollution 216:135-145. https://doi.org/10.1016/j.envpol.2016.05.062

Hardison D.W., Ma L.Q., Loungo T. and Harris W.G. (2004) Lead contamination in shooting range soils from abrasion of lead bullets and subsequent weathering. Science of the Total Environment 328:175-183. https://doi.org/10.1016/j.scitotenv.2003.12.013

\section{Conclusions}

The study highlighted changes in soil characteristics $(\mathrm{pH}$, organic matter, and soil density) and the contamination with heavy metals of the shooting range soil. The $\mathrm{pH}$ value of the shooting range soil was more alkaline, lower in organic matter content (especially in the backstop berm soil), and higher in soil density. The shooting range soil contained elevated $\mathrm{Pb}$ and $\mathrm{Cu}$ concentrations, which are mostly concentrated in the backstop berm; $\mathrm{Ni}$ and $\mathrm{Cd}$ were mostly concentrated in the area of the shooting range ( $0-400$ meters). The limit concentrations of $\mathrm{Pb}, \mathrm{Cd}$, Ni were exceeded in soil samples of the shooting range. Further studies describing contamination mitigation techniques are required.

Islam, M. and Park, J. (2017) Immobilization and reduction of bioavailability of lead in shooting range soil through hydrothermal treatment. Journal of Environmental Management 191:172-178. https://doi.org/10.1016/j.jenvman.2017.01.017

Kelebemang R., Dinake P., Sehube N., Daniel B., Totolo O. and Laetsang M. (2017) Speciation and mobility of lead in shooting range soils. Chemical Speciation \& Bioavailability 29(1):143152. https://doi.org/10.1080/09542299.2017.1349552

Khalilova H. and Mammadov V. (2016) Assessing the Anthropogenic Impact on Heavy Metal Pollution of Soils and Sediments in Urban Areas of Azerbaijan's Oil Industrial Region. Pol. J. Environ. Stud. 25(1):159-166. https://doi.org/10.15244/pjoes/60723

Kučerík, J., Tokarski, D., Demyan, M., Merbach, I. and Siewert, C. (2018). Linking soil organic matter thermal stability with contents of clay, bound water, organic carbon and nitrogen. Geoderma 316:38-46. https://doi.org/10.1016/j.geoderma.2017.12.001

Mariussen E., Heier L. S., Teien H.C., Pettersen M.N., Holth T. F., Salbu B., and Rosseland B.O. (2017) Accumulation of lead (Pb) in brown trout (Salmo trutta) from a lake downstream a former shooting range. Ecotoxicology and Environmental Safety 135 : 327-336. https://doi.org/10.1016/j.ecoenv.2016.10.008

Murray K., Bazzi A., Carter C., Ehlert A., Ham's A., Kopec M., Richardson J. and Sokol H. (1997) Distribution and Mobility of Lead in Soils at an Outdoor Shooting Range. Journal of Soil Contamination 6(l):79-93. https://doi.org/10.1080/15320389709383547

Perroy R. L., Belby S. C. and Mertens C. D. (2014) Mapping and modeling three dimensional lead contamination in the wetland 
sediments of a former trap-shooting range. Science of the Total Environment 487:72-81. https://doi.org/10.1016/j.scitotenv.2014.03.102

Rodríguez-Seijo A., Cachada A., Gavina A., Duarte A.C., Vega F.A., Andrade M.L. and Pereira R. (2017) Lead and PAHs contamination of an old shooting range: A case study with a holistic approach. Science of the Total Environment 575:367-377. https://doi.org/10.1016/j.scitotenv.2016.10.018

Sanderson P., Naidu R. and Bolana N. (2014) Ecotoxicity of chemically stabilised metal(loid)s in shooting range soils. Ecotoxicology and Environmental Safety 100:201-208. https://doi. org/10.1016/j.ecoenv.2013.11.003

Sanderson P., Naidua R., Bolana N., Bowmanc M. and Mclurea S. (2012) Effect of soil type on distribution and bioaccessibility of metal contaminants in shooting range soils. Science of The Total Environment 438:452-462. https://doi.org/10.1016/j.scitotenv.2012.08.014

Seshadri, B., Bolan, N., Choppala, G., Kunhikrishnan, A., Sanderson, P., Wang, H., Currie, L., Tsang, D., Ok, Y. and Kim, G. (2017) Potential value of phosphate compounds in enhancing immobilization and reducing bioavailability of mixed heavy metal contaminants in shooting range soil. Chemosphere 184:197-206.
Sorvari J., Antikainen R. and Pyy O. (2006) Environmental contamination at Finnish shooting ranges - the scope of the problem and management options. Science of the Total Environment 366: 21-31.

Spuller C., Weigand H. and Marb C. (2007) Trace metal stabilisation in a shooting range soil: Mobility and phytotoxicity. Journal of Hazardous Materials 141:378-387. https://doi.org/10.1016/j. jhazmat.2006.05.082

Tandy S., Meier N. and Shullin R. (2017) Use of soil amendments to immobilize antimony and lead in moderately contaminated shooting range soils. Journal of Hazardous Materials 324(Part B): 617-625. https://doi.org/10.1016/j.jhazmat.2016.11.034

Tchounwou P. B., Yedjou C.G., Patlolla A. K. and Sutton J. D. (2012) Heavy Metals Toxicity and the Environment. Molecular, Clinical and Environmental Toxicology 101:133-164. https://doi. org/10.1007/978-3-7643-8340-4_6

Zeng F., Shafaqat A., Zhang H., Ouyang Y., Qiu B., Wu F. and Zhang G. (2011) The influence of pH and organic matter content in paddy soil on heavy metal availability and their uptake by rice plants. Environmental Pollution 159:84-91. https://doi. org/10.1016/j.envpol.2010.09.019 